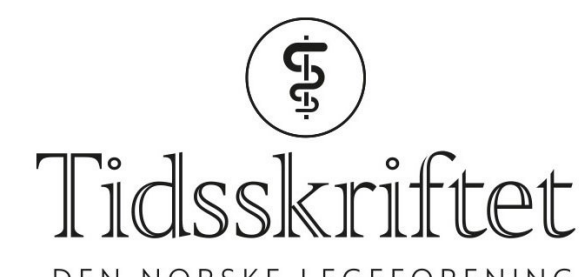

DEN NORSKE LEGEFORENING

\title{
Per Fugelli
}

MINNEORD

ARILD BJØRNDAL

CHRISTIAN F. BORCHGREVINK

JAN FRICH

PÅL GULBRANDSEN

ANNE KVEIM LIE

KIRSTI MALTERUD

JOHN-ARNE RØTTINGEN

GUNNAR TELLNES

STEINAR WESTIN

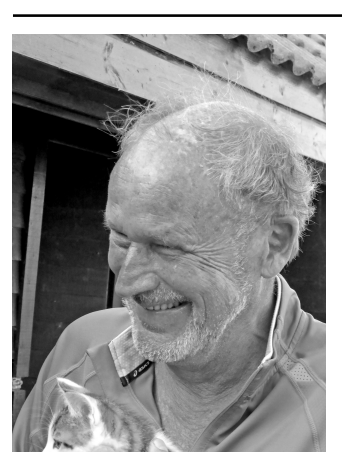

Per Fugelli døde 13. september 2017, 73 år gammel. Den siste sommeren tilbrakte han og Charlotte i et landskap han elsket. Han fikk også dø der på jæren, omgitt av barn og barnebarn. Dagene gikk i pluss, som han selv formulerte det, helt til det siste.

Per er kjent for sitt engasjement for rettferdighet, solidaritet og en klok helsetjeneste. De åtte årene med kreftsykdommen møtte tusenvis frem over hele landet for å høre ham snakke om et ærlig samliv med døden. Helt til det siste var han klar og tydelig: Norge fortjener takk for å ha bygd en sterk velferdsstat og samtidig økt den personlige friheten, skrev han i Aftenposten 9. august 2017. Han minnet om at rettferdighet, tillit og frihet ikke 
er permanente størrelser, men noe vi må ville og velge.

Allmennmedisinen var Pers faglige utgangspunkt. Erfaringene fra Værøy og Røst preget ham hele livet. I Bergen bygde han et sterkt akademisk miljø fra midten av 1980-årene. For oss som var vevet inn i hans faglige liv var det ingen overraskelse da han senere meldte overgang til sosialmedisinen og videreutviklet sitt særegne talent for medisinsk samfunnskritikk. I det offentlige rom deltok han med en uvanlig glede. Det var ikke bare formuleringskunsten mange kom til å elske, men også respekten for folk og folkevettet. Han var ikke alltid like heldig med sin retoriske akrobatikk, som da han lanserte begrepet «EUsykdommene». Kritikken av Helsedirektoratets «talibanmetoder» og enkelte andre debattknep ble oppfattet som nedlatende. Men Per kunne beklage når metaforene kom i veien for budskapet.

Per utviklet undervisning i utkanten av pensum, som med «Pasienten Jorden», en arbeidsgruppe for miljø- og utviklingsmedisin. Vi som skriver dette har selv på ulike måter opplevd hvordan han løftet frem viktige temaer og bidro til å skape ny mening for studenter som savnet glød og trengte inspirasjon. Vi har erfart hvordan samvær og avgjørende møter med Per ble til heiarop og motforestillinger som fikk stor betydning ved personlige og faglige veivalg. «Ta risiko og tål litt kjeft», sa han gjerne. Han var en god mentor og samtidig en trofast venn.

Norge har mistet raushetens bakvakt. Norsk medisin har mistet sin skarpeste penn. Den store og den lille flokken har mistet en klok, munter, lekende og varm høvding. Men han ville ikke at noen skulle stå ved hans grav og klage. Vi var utrolig heldige som hadde ham så lenge. Nå er det vår - og din - vakt.

Publisert: 29. september 2017. Tidsskr Nor Legeforen. DOI: 10.4045/tidsskr.17.080o

(C) Tidsskrift for Den norske legeforening 2020. Lastet ned fra tidsskriftet.no 